Published in final edited form as:

ACS Appl Mater Interfaces. 2019 October 23; 11(42): 38531-38536. doi:10.1021/acsami.9b14651.

\title{
Covalent Attachment of P15 Peptide to Ti Alloy Surface Modified with Polymer to Enhance Osseointegration of Implants
}

\author{
Liye Fu ${ }^{\dagger}, \#$, Maiko Omi ${ }^{\ddagger}, \#$, Mingkang Sun ${ }^{\dagger}$, Boyle Cheng ${ }^{\S}$, Gordon Mao§, Tong Liu ${ }^{\dagger}$, Gustavo \\ Mendonça ${ }^{\ddagger}$, Saadyah E. Averick ${ }^{*} \S$, Yuji Mishina ${ }^{*}, \neq$, Krzysztof Matyjaszewski ${ }^{*}{ }^{\star} \dagger$ \\ tDepartment of Chemistry, Carnegie Mellon University, Pittsburgh, Pennsylvania 15213, United \\ States
}

‡Department of Biologic and Materials Sciences \& Prothodontics, University of Michigan School of Dentistry, Ann Arbor, Michigan 48109, United States

§Neuroscience Disruptive Research Lab, Allegheny Health Network, 320 East North Avenue, Pittsburgh, Pennsylvania 15212, United States

\begin{abstract}
Titanium (Ti) and its alloys are used in orthopedic and dental implants due to their excellent physical properties and biocompatibility. Although Ti exhibits superior osteoconductive properties compared to those of polymer-based implants, improved bone-on growth properties are required for enhanced surgical outcomes and improved recovery surgical interventions. Herein, we demonstrate a novel surface modification strategy to enhance the osteoconductivity of Ti surfaces through the grafting-from procedure of a reactive copolymer via surface-initiated atom transfer radical polymerization (SI-ATRP). Then, postpolymerization conjugation of the P15 peptide, an osteoblast binding motif, was successfully carried out. Subsequent in vitro studies revealed that the surface modification promoted osteoblast attachment on the Ti discs at 6 and $24 \mathrm{~h}$. Moreover, mineral matrix deposition by osteoblasts was greater for the surface-modified $\mathrm{Ti}$ than for plain $\mathrm{Ti}$ and P15 randomly absorbed onto the Ti surface. These results suggest that the strategy for postpolymerization incorporation of P15 onto a Ti surface with a polymer interface may provide improved osseointegration outcomes, leading to enhanced quality of life for patients.
\end{abstract}

\section{Graphical Abstract}

\footnotetext{
*Corresponding Authors: saadyah.averick@ahn.org (S.E.A.). mishina@umich.edu (Y.M.). km3b@andrew.cmu.edu (K.M.). \#L.F. and M.O. contributed equally to this work.

Supporting Information

The Supporting Information is available free of charge on the ACS Publications website at DOI: 10.1021/acsami.9b14651.

Characterization of aqueous phase catalysts and polymerization results (PDF)

The authors declare no competing financial interest.
} 


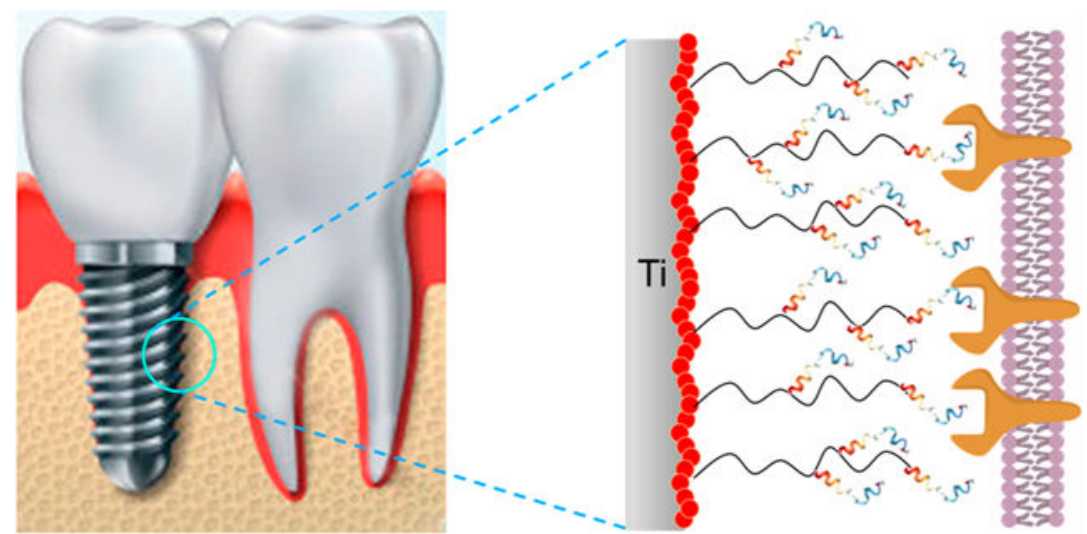

P15-polymer Modified Ti Surface for Rapid Osseointegration

\begin{abstract}
Keywords
titanium; implant; osseointegration; surface modification; polymer grafting; P15 peptide; SI-ATRP
\end{abstract}

\title{
INTRODUCTION
}

Titanium (Ti) alloys are the most commonly used materials in spine, orthopedic, and dental implants due to their low modulus, superior biocompatibility, enhanced corrosion resistance, and osteoconductive properties when compared to more conventional stainless-steel- and cobalt-based alloys. ${ }^{1-3}$ Osseointegration of implants is characterized as the direct structural and functional connection between living bone and the surface of a load-bearing artificial implant. ${ }^{4}$ Ideally, implant materials facilitate functional tissue regeneration of bones in addition to providing structural support of damaged tissue. Dental implants are a wellestablished treatment for replacing lost teeth and have achieved high success rates. Unfortunately, all implant materials including Ti-based implants require a several months long postimplantation period before fixation and bone growth on implanted materials in otherwise healthy individuals. In the case of heavy smokers, or patients with severe diabetes or osteoporosis, there are higher rates of implant failure due to impaired bone healing. 5,6 The negative outcomes of poor osseointegration with insufficient bone healing need to be improved for successful implant application in challenging cases. ${ }^{7,8}$ Therefore, novel technologies that can enhance osteoconductive properties of Ti and thus facilitate osseointegration are of great medical importance.

The success of an implant's osseointegration is dictated by the cell-biomaterial interactions that are primarily governed by cell adhesion originating from the binding of cellular integrin receptors to the material's surface. ${ }^{9}$ Enhancement of binding can be achieved by attaching biomacromolecules via adsorption, tethering, or deposition onto the implants. Osteoblastic differentiation requires binding of $a 2 \mathrm{~B} 1$ integrins with type I collagen ${ }^{10}$ which initiates activation of focal adhesion kinases (FAK) leading to signal transduction pathways involved in cell migration, survival, and differentiation. ${ }^{11}$ Incorporation of $a 2 \mathrm{~B} 1$ binding motifs onto implant-body interfaces can promote osseointegration of biomaterials. ${ }^{12,13}$ The P15 peptide is a synthetic short peptide (GTPGPQGIAGQRGVV) that mimics the cell-binding domain 
of human type I collagen and has found applications in coating the surface of inorganic bone material to promote osteoblast differentiation and to enhance cell adhesion, migration, and survival. ${ }^{14,15}$ In addition to promoting cell adhesion, exposure of the P15 peptide to mesenchymal stem cells leads to express higher alkaline phosphatase activity, a marker of early osteoblast differentiation. ${ }^{16-18}$ It was reported that nonspecific absorption of the P15 peptide onto a Ti alloy surface leads to improvements of cell growth, but it had limited impact on in vitro matrix mineralization. ${ }^{19}$

An additional tool to enhance implant biocompatibility and osseointegration is the coating of biomolecule-polymer hybrids onto the metal surface. A surface coating consisting of polymers with an integrin binding domain (the RGD peptide) increases the bone-implant contact area by $75 \%$ when compared to that with an uncoated Ti surface. ${ }^{20}$ Thus, combining polymers and integrin binding motifs may play a key role in the next generation implants with an increased cellular integration and potentially faster osseointegration.

A key challenge to preparing these complex hybrid materials is the grafting of a uniform polymer layer at the metal interface. Recent advances in reversible deactivation radical polymerization (RDRP) methods like atom transfer radical polymerization (ATRP) have ameliorated many challenges to preparing polymer-modified surfaces for applications in energy, self-cleaning, and superhydrophilic materials. ${ }^{21-24}$ Nevertheless, application of polymer-grafted metal surfaces in the biomedical space is still very limited. To prepare uniform layers of polymers from a metal surface, initiators are first immobilized onto a surface, then monomers are introduced, and polymers are grown in situ via a surfaceinitiated atom transfer radical polymerization (SI-ATRP), which is a versatile and robust approach widely used in the "graft-from" strategy. ${ }^{25-28}$ We hypothesized that the incorporation to the $\mathrm{P} 15$ peptide onto surfaces grafted with polymers would be a facile method to improve cell binding and in vitro mineralization of osteoblasts onto a Ti surface.

In this manuscript, we developed a novel method of attaching polymers and P15 peptide on the surface of Ti materials to enhance in vitro osseointegration. Ti discs were processed using an acid etch, followed by treatment of a tethering agent containing ATRP initiator 12(2-bromoisobutyramido)dodecanoic acid (BiBADA). A monomer containing a ketone moiety, acetylethyl methacrylate (AEMA), was synthesized and copolymerized with 2(dimethylamino) ethyl methacrylate (DMAEMA) via SI-ATRP. The ketone-containing polymer grafted from the Ti surface allowed for postpolymerization ligation of the P15 peptide with aminooxy-modified $\mathrm{N}$-terminus via oxime chemistry. ${ }^{29}$ The in vitro impact of polymer grafting was studied using short-term cell binding assays and late-stage mineralization studies using primary osteoblasts. Our results showed the improved osteoconductive cellular response including cell attachment and mineralization to the polymer-modified Ti surface compared to that on the untreated Ti surface.

\section{EXPERIMENTAL SECTION}

\section{Modification of the Ti Surface.}

Titanium discs (United Performance Metals, South Windsor, CT) (99\% Ti, $1.0 \mathrm{~mm}$ thick, $14.7 \mathrm{~mm}$ in diameter) were cleaned by washing twice in $1 \mathrm{M} \mathrm{NaOH}$ with sonication for 5 
min, twice in deionized water $\left(\mathrm{dH}_{2} \mathrm{O}\right)$, and twice in $\mathrm{MeOH} / \mathrm{HCl}$ (50:50) with sonication for $30 \mathrm{~min}$, then etching by piranha solution (50:50, 98\% $\mathrm{H}_{2} \mathrm{SO}_{4} / 30 \% \mathrm{H}_{2} \mathrm{O}_{2}, 4 \mathrm{~h}$ ), and subsequently washing twice in $\mathrm{dH}_{2} \mathrm{O}$ with sonication for $5 \mathrm{~min}$ and thrice with tetrahydrofuran (THF) for $5 \mathrm{~min}$. To attach the ATRP initiator, the discs were treated with BiBADA ( $10 \mathrm{mg} / \mathrm{mL}$ in THF) with sonication for $2 \mathrm{~h}$, followed by washing twice in THF for $5 \mathrm{~min}$. Then, the Ti discs were dried under vacuum and placed in desiccator prior to use.

\section{Polymer Grafting and P15 Attachment.}

Ti discs (maximum of 5 per reaction) were placed into a $50 \mathrm{~mL}$ round-bottomed Schlenk flask DMAEMA (1.866 g, $11.88 \mathrm{mmol})$, AEMA (0.928 g, $5.94 \mathrm{mmol})$, and sacrificial initiator 2-hydroxyethyl $a$-bromoisobutyrate (OHEBiB, $25.1 \mathrm{mg}, 0.12 \mathrm{mmol}$ ) were added to the flask. Next, $530 \mu \mathrm{L}$ stock solution of copper(II) bromide and tris(2-pyridylmethyl)amine $\left(\mathrm{CuBr}_{2} / \mathrm{TPMA}=1: 5,5.0 \mathrm{mg} / \mathrm{mL}\right.$ of $\left.\mathrm{CuBr}_{2}\right)$ was pipetted into the flask, and $\mathrm{N}, \mathrm{N}-$ dimethylformamide (DMF) was added to a total of $20 \mathrm{~mL}$ of reaction mixture. The flask was then sealed and purged by bubbling $\mathrm{N}_{2}$ gas. Photomediated ATRP was conducted under irradiation by a $4.9 \mathrm{~mW} / \mathrm{cm}^{2} \mathrm{UV}$ lamp for $5 \mathrm{~h}$. P15 with an aminooxy $\mathrm{N}$-terminal end was purchased from Genscript. A $2 \mathrm{mg} / \mathrm{mL}$ solution of $\mathrm{P} 15-\mathrm{ONH}_{2}$ was prepared in $1 \times \mathrm{PBS}$.

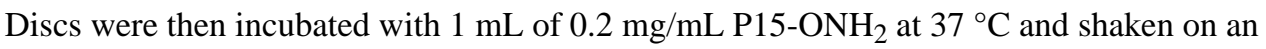
orbital plate shaker for $24 \mathrm{~h}$. Discs were washed with PBS, water, and 70\% ethanol/water. A total of 4 groups of Ti discs were prepared for in vitro studies: (1) pristine Ti discs without any modification or treatment (Ti); (2) Ti discs with adsorption of P15 peptide ( $\mathrm{Ti}+\mathrm{P} 15)$; (3) polymer-grafted Ti discs without P15 peptide (Ti-polymer); and (4) polymer-grafted Ti discs with P15 peptide (Ti-polymer + P15) (Scheme 1).

\section{Cell Viability Assay.}

Wild-type preosteoblasts were isolated from newborn mouse calvaria and cultured in alphaminimum essential medium ( $a \mathrm{MEM}$ ) supplemented with $10 \%$ fetal bovine serum (Denville Scientific) and 1\% penicillin/streptomycin (Invitrogen). All cells were used for experiments before passage 4 . To assess cell adhesion, osteoblasts were seeded onto Ti discs $\left(1 \times 10^{5}\right.$ cells/disc) and cultured for $6 \mathrm{~h}$. After washing nonadherent cells, the osteoblasts attached to the Ti discs were incubated with culture media also containing $10 \%$ (v/v) alamarBlue reagent (Invitrogen) for $4 \mathrm{~h}$. At the end of cultivation, $100 \mu \mathrm{L}$ of the culture media was transferred to a 96-well plate in triplicate for each sample, and levels of $580 \mathrm{~nm}$ emission were measured with $530 \mathrm{~nm}$ excitation using a fluorescence plate reader to quantify conversion of resazurin to resorufin as a surrogate of attached live cells on the Ti discs.

\section{Phalloidin Stain and Cell Count.}

Osteoblasts were cultured on the Ti discs $\left(1 \times 10^{5}\right.$ cells/disc) for $24 \mathrm{~h}$ and fixed with $4 \%$ paraformaldehyde. Cells were subsequently stained with Acti-stain 488 phalloidin (Cytoskeleton) and 4' 6-diamidino-2-phenylindole (DAPI) (Invitrogen) overnight at $4{ }^{\circ} \mathrm{C}$. Fluorescence images were taken using a $\mathrm{C} 1$ confocal microscope (Nikon), and at least 10 fields per sample were counted. 


\section{Alizarin Red S Stain.}

Osteoblasts were seeded onto the Ti discs $\left(1 \times 10^{5}\right.$ cells/disc $)$ and incubated with osteogenic differentiation media containing $10 \mathrm{mM} \beta$-glycerophosphate and $50 \mu \mathrm{g} / \mathrm{mL}$ L-ascorbic acid. After 21 days in culture, cells were fixed with $70 \%$ ethanol for $15 \mathrm{~min}$ at room temperature. Cells were stained with $40 \mathrm{mM}$ alizarin red S (Sigma-Aldrich) for $10 \mathrm{~min}$ and then rinsed five times with water to minimize nonspecific staining. The stained area was digitally photographed and analyzed by using ImageJ (National Institutes of Health). Then, 10\% cetylpyridinium chloride (Sigma-Aldrich) was used to dissolve bound alizarin red S, and optical density was measured at $562 \mathrm{~nm}$.

\section{Statistical Analysis.}

All results were expressed as means \pm standard deviation (means \pm SD) of triplicate measurements. Statistical differences among the three groups were analyzed using one-way ANOVA, followed by a Tukey's test. Values of $p<0.05$ were considered significant.

\section{RESULTS AND DISCUSSIONS}

\section{Polymer Grafting from Surface Roughened Ti Discs.}

In this study, the surface of the Ti discs was washed by sonication under acidic and basic conditions, followed by acid etching using piranha solution, resulting in dull colored discs and indicative of surface-roughened Ti. ${ }^{30}$ After surface roughening, the BiBADA ATRP initiator was immobilized via combination of ionic and hydrophobic interaction as previously reported. ${ }^{31}$ SI-ATRP was conducted using a photoregenerated catalysts. ${ }^{32-35}$ The grafted polymer had $M_{\mathrm{n}}=12400$ with low dispersity $\left(~ D=M_{\mathrm{w}} / M_{\mathrm{n}}=1.38\right)$, as determined by gel permeation chromatography (GPC) using sacrificial initiator, ${ }^{36}$ (Figure S1) with a monomer conversion reaching 54\% after $5 \mathrm{~h}$ of photomediated ATRP. X-ray photoelectron spectroscopy (XPS) was used to evaluate the extent of surface modification at each stage of the Ti modification process including initiator immobilization and polymer grafting. At two positions, Ti signals ( 458 and $465 \mathrm{eV}$ ) were visible before the polymerization but disappeared afterward, indicating the surface of Ti discs were covered by a layer of polymer (Figure 1). In addition, results of atom mass percentage analyses also indicated a decrease of the Ti content with a progressive increase of $\mathrm{C}$ and $\mathrm{N}$ content. (Table S1). The modification was also proved by analysis of scanning electron microscopy (SEM) showing the surface of Ti plate was covered by a fine layer of polymer (Figure S2). The monomers grafted from the discs were selected to maximize interaction with the extracellular matrix (ECM) $)^{37}$ and afford a postsynthetic reactive handle for P15 incorporation. DMAEMA was the primary constituent of the random copolymer giving the grafted surface a positive charge that can interact with the negatively charged proteoglycans in the ECM and on cell surfaces. The AEMA monomer was synthesized via a one-step reaction (Scheme S1) and provided ketone functionality on the side chains of the polymer. This group is orthogonally reactive to biological molecules and can be selectively activated and reacted with $N$-aminooxyfunctionalized compounds such as P15 peptide derivative through oxime chemistry (Scheme $\mathrm{S} 2$ ). The ketoxime linking group is formed rapidly and efficiently and is stable against hydrolysis at $\mathrm{pH} 5.0-9.0 .^{38}$ 


\section{Cell Binding to Ti-Polymer-Grafted Surfaces.}

To address whether the surface modification technique can improve cell adhesion onto the $\mathrm{Ti}$ discs, cell viability at 6 and $48 \mathrm{~h}$ was measured by alamarBlue. The viability of cells on the polymer-modified Ti surface with P15 peptides (Ti-polymer + P15) was higher than that on the plain Ti surface (Figure 2a). However, the cell viability on the polymer-modified Ti surface without P15 peptides (Ti-polymer) was similar to that on the plain Ti surface. These results suggested that modification of the Ti surface by grafting polymer with P15 peptides enhances cell attachment and growth. Next, we investigated whether attaching polymers and P15 peptides on the Ti surface improves cell attachment on the Ti materials compared to that with the plain Ti and the P15-adsorbed plain Ti surface. Cell viability at $6 \mathrm{~h}$ and cell number at $24 \mathrm{~h}$ after seeding were measured by alamarBlue and nuclei staining, respectively. The viability of cells on the polymer-modified Ti surface with P15 peptides (Ti-polymer + P15) was significantly higher than that on the plain Ti or the P15-adsorbed plain Ti surface (plain $\mathrm{Ti}+\mathrm{P} 15$ ) (Figure 2b). Fluorescent phalloidin staining showed that cells on the polymermodified Ti with P15 peptides were more numerous and tightly packed compared to cells on the plain Ti or the P15 peptides to the plain Ti surface (Figure 2c). The number of cells adherent to the polymer-modified Ti surface with P15 peptides was significantly higher than that to the plain Ti or the P15-adsorbed Ti surface (Figure 2d). To address whether the surface modification technique can promote osteoblast differentiation, the expression of the typical osteoblast early markers Col1a1 and Alp was determined by qRT-PCR. Colla1 expression significantly increased in cells on the polymer-modified Ti surface with P15 peptides compared to that in cells on the plain Ti or the P15-adsorbed plain Ti surface, while Alp expression had similar levels among all the groups (Figure S3). These results suggest that the surface modification technique using polymers and P15 peptides enhances cell attachment on the Ti surface and osteoblast differentiation, and the major reason was deemed to be a larger surface area created by grafted polymer densely attached with P15 peptides.

To determine whether the polymer-grafted Ti discs promote mineralization in osteoblasts, calcium deposits in cell culture were visualized by Alizarin red S staining at 21 days (Figure 3a). Osteoblasts cultured on the polymer-modified Ti surface with P15 peptides significantly increased calcium deposition compared to those cultured on the plain Ti or the P15-adsorbed plain Ti surface (Figure 3b,c). These results indicate that the surface modification technique using polymers and P15 peptides indeed enhances osteoblast mineralization.

\section{CONCLUSIONS}

In summary, we have successfully modified the Ti surface by grafting polymer via SI-ATRP. With the attachment of P15 peptide to the polymer via oxime chemistry, our results showed the improved cell adhesion of osteoblasts to the Ti surface. In addition, the mineralization assay showed the higher calcium deposition by osteoblasts seeded on the polymer-modified Ti surface discs. Although surface-modified Ti displays superior in vitro osteoconductivity compared to that of plain $\mathrm{Ti}$, further in vivo studies are needed to fully demonstrate the efficacy of our surface modification technique for improved osseointegration. In conclusion, we developed a novel process to dramatically enhance the potential osteoconductive nature 
of Ti surface, which may provide better results for osseointegration of orthopedic and dental implants.

\section{Supplementary Material}

Refer to Web version on PubMed Central for supplementary material.

\section{ACKNOWLEDGMENTS}

The support from NIH R01 DE020843 and the Army Research Office (Award\# 68271-CH) are acknowledged. We thank Dr. William Giannobile and Dr. Fei Liu for advice on research strategy. We thank Dr. Hiroki Ueharu and Dr. Yijun Zhou for technical advice.

\section{REFERENCES}

(1). Long M; Rack HJ Titanium Alloys in Total Joint Replacement - a Materials Science Perspective. Biomaterials 1998, 19 (18), 1621-1639. [PubMed: 9839998]

(2). Guillemot F Recent Advances in the Design of Titanium Alloys for Orthopedic Applications. Expert Rev. Med. Devices 2005, 2 (6), 741-748. [PubMed: 16293101]

(3). Geetha M; Singh AK; Asokamani R; Gogia AK Ti Based Biomaterials, the Ultimate Choice for Orthopaedic Implants - a Review. Prog. Mater. Sci 2009, 54 (3), 397-425.

(4). Schenk RK; Buser D Osseointegration: A Reality. Periodontol. 2000 1998, 17 (1), 22-35. [PubMed: 10337310]

(5). Esposito M; Hirsch JM; Lekholm U; Thomsen P Biological Factors Contributing to Failures of Osseointegrated Oral Implants - (Ii). Etiopathogenesis. Eur. J. Oral Sci. 1998, 106 (3), 721-764. [PubMed: 9672097]

(6). Tsao AK; Jones LC; Lewallen DG What Patient and Surgical Factors Contribute to Implant Wear and Osteolysis in Total Joint Arthroplasty? J. Am. Acad. Orthop. Sur 2008, 16, S7-S13.

(7). van Steenberghe D; Jacobs R; Desnyder M; Maffei G; Quirynen M The Relative Impact of Local and Endogenous Patient-Related Factors on Implant Failure up to the Abutment Stage. Clin. Oral. Implan. Res 2002, 13 (6), 617-622.

(8). Goodacre CJ; Bernal G; Rungcharassaeng K; Kan JY K. Clinical Complications with Implants and Implant Prostheses. J. Prosthet. Dent 2003, 90 (2), 121-132. [PubMed: 12886205]

(9). Franz S; Rammelt S; Scharnweber D; Simon JC Immune Responses to Implants - a Review of the Implications for the Design of Immunomodulatory Biomaterials. Biomaterials 2011, 32 (28), 6692-6709. [PubMed: 21715002]

(10). Mizuno M; Fujisawa R; Kuboki Y Type I Collagen-Induced Osteoblastic Differentiation of BoneMarrow Cells Mediated by Collagen- $a 2 \beta 1$ Integrin Interaction. J. Cell. Physiol 2000, 184 (2), 207-213. [PubMed: 10867645]

(11). Hynes RO Integrins - Versatility, Modulation, and Signaling in Cell-Adhesion. Cell 1992, 69 (1), 11-25. [PubMed: 1555235]

(12). Kim KH; Ramaswamy N Electrochemical Surface Modification of Titanium in Dentistry. Dent. Mater. J 2009, 28 (1), 20-36. [PubMed: 19280965]

(13). Kassick AJ; Yerneni SS; Gottlieb E; Cartieri F; Peng Y; Mao G; Kharlamov A; Miller MC; Xu C; Oh M; Kowalewski T; Cheng B; Campbell PG; Averick S Osteoconductive Enhancement of Polyether Ether Ketone: A Mild Covalent Surface Modification Approach. ACS Appl. Bio Mater. 2018, 1 (4), 1047-1055.

(14). Hanks T; Atkinson BL Comparison of Cell Viability on Anorganic Bone Matrix with or without P-15 Cell Binding Peptide. Biomaterials 2004, 25 (19), 4831-4836. [PubMed: 15120530]

(15). Li X; Contreras-Garcia A; LoVetri K; Yakandawala N; Wertheimer MR; De Crescenzo G; Hoemann CD Fusion Peptide P15-Csp Shows Antibiofilm Activity and Pro-Osteogenic Activity When Deposited as a Coating on Hydrophilic but Not Hydrophobic Surfaces. J. Biomed. Mater. Res., Part A 2015, 103 (12), 3736-3746. 
(16). Bhatnagar RS; Qian JJ; Gough CA The Role in Cell Binding of a Beta-Bend within the Triple Helical Region in Collagen Alpha 1(I) Chain: Structural and Biological Evidence for Conformational Tautomerism on Fiber Surface. J. Biomol. Struct. Dyn 1997, 14 (5), 547-560. [PubMed: 9130077]

(17). Hennessy KM; Pollot BE; Clem WC; Phipps MC; Sawyer AA; Culpepper BK; Bellis SL The Effect of Collagen I Mimetic Peptides on Mesenchymal Stem Cell Adhesion and Differentiation, and on Bone Formation at Hydroxyapatite Surfaces. Biomaterials 2009, 30 (10), 1898-1909. [PubMed: 19157536]

(18). Balic A; Aguila HL; Caimano MJ; Francone VP; Mina M Characterization of Stem and Progenitor Cells in the Dental Pulp of Erupted and Unerupted Murine Molars. Bone 2010, 46 (6), 1639-1651. [PubMed: 20193787]

(19). Liu Q; Limthongkul W; Sidhu G; Zhang J; Vaccaro A; Shenck R; Hickok N; Shapiro I; Freeman T Covalent Attachment of P15 Peptide to Titanium Surfaces Enhances Cell Attachment, Spreading, and Osteogenic Gene Expression. J. Orthop. Res 2012, 30 (10), 1626-1633. [PubMed: 22504956]

(20). Gomar F; Orozco R; Villar JL; Arrizabalaga F P-15 Small Peptide Bone Graft Substitute in the Treatment of Non-Unions and Delayed Union. A Pilot Clinical Trial. Int. Orthop 2007, 31 (1), 93-99. [PubMed: 16761146]

(21). Hui CM; Pietrasik J; Schmitt M; Mahoney C; Choi J; Bockstaller MR; Matyjaszewski K SurfaceInitiated Polymerization as an Enabling Tool for Multifunctional (Nano-)Engineered Hybrid Materials. Chem. Mater 2014, 26 (1), 745-762.

(22). Matyjaszewski K Advanced Materials by Atom Transfer Radical Polymerization. Adv. Mater 2018, 30 (23), 1706441.

(23). Matyjaszewski K; Xia JH Atom Transfer Radical Polymerization. Chem. Rev 2001, 101 (9), 2921-2990. [PubMed: 11749397]

(24). Tischer T; Claus TK; Bruns M; Trouillet V; Linkert K; Rodriguez-Emmenegger C; Goldmann AS; Perrier S; Borner HG; Barner-Kowollik C Spatially Controlled Photochemical Peptide and Polymer Conjugation on Biosurfaces. Biomacromolecules 2013, 14 (12), 4340-4350. [PubMed: 24127628]

(25). Pyun J; Kowalewski T; Matyjaszewski K Synthesis of Polymer Brushes Using Atom Transfer Radical Polymerization. Macromol. Rapid Commun. 2003, 24 (18), 1043-1059.

(26). Zoppe JO; Cavusoglu Ataman N; Mocny P; Wang J; Moraes J; Klok H-A Surface-Initiated Controlled Radical Polymerization: State-of-the-Art, Opportunities, and Challenges in Surface and Interface Engineering with Polymer Brushes (Vol 117, Pg 1105, 2017). Chem. Rev 2017, 117 (5), 4667-4667. [PubMed: 28221035]

(27). Matyjaszewski K; Dong HC; Jakubowski W; Pietrasik J; Kusumo A Grafting from Surfaces for "Everyone": ARGET ATRP in the Presence of Air. Langmuir 2007, 23 (8), 4528-4531. [PubMed: 17371060]

(28). Yan W; Fantin M; Ramakrishna S; Spencer ND; Matyjaszewski K; Benetti EM Growing Polymer Brushes from a Variety of Substrates under Ambient Conditions by $\mathrm{Cu}(0)$-Mediated SurfaceInitiated ATRP. ACS Appl. Mater. Interfaces 2019, 11 (30), 27470-27477. [PubMed: 31276375]

(29). Mukherjee S; Bapat AP; Hill MR; Sumerlin BS Oximes as Reversible Links in Polymer Chemistry: Dynamic Macromolecular Stars. Polym. Chem 2014, 5 (24), 6923-6931.

(30). Ketonis C; Parvizi J; Adams CS; Shapiro IM; Hickok NJ Topographic Features Retained after Antibiotic Modification of Ti Alloy Surfaces: Retention of Topography with Attachment of Antibiotics. Clin. Orthop. Relat. Res 2009, 467 (7), 1678-1687. [PubMed: 19365697]

(31). Yan J; Pan X; Wang Z; Lu Z; Wang Y; Liu L; Zhang J; Ho C; Bockstaller MR; Matyjaszewski K A Fatty Acid-Inspired Tetherable Initiator for Surface-Initiated Atom Transfer Radical Polymerization. Chem. Mater 2017, 29 (11), 4963-4969.

(32). Averick S; Simakova A; Park S; Konkolewicz D; Magenau AJD; Mehl RA; Matyjaszewski K ATRP under Biologically Relevant Conditions: Grafting from a Protein. ACS Macro Lett. 2012, 1 (1), 6-10.

(33). Konkolewicz D; Schroder K; Buback J; Bernhard S; Matyjaszewski K Visible Light and Sunlight Photoinduced ATRP with ppm of Cu Catalyst. ACS Macro Lett. 2012, 1 (10), 1219-1223. 
(34). Pan XC; Fantin M; Yuan F; Matyjaszewski K Externally Controlled Atom Transfer Radical Polymerization. Chem. Soc. Rev 2018, 47 (14), 5457-5490. [PubMed: 29868657]

(35). Ribelli TG; Konkolewicz D; Bernhard S; Matyjaszewski K How Are Radicals (Re)Generated in Photochemical ATRP? J. Am. Chem. Soc 2014, 136 (38), 13303-13312. [PubMed: 25178119]

(36). von Werne TA; Germack DS; Hagberg EC; Sheares VV; Hawker CJ; Carter KR A Versatile Method for Tuning the Chemistry and Size of Nanoscopic Features by Living Free Radical Polymerization. J. Am. Chem. Soc 2003, 125 (13), 3831-3838. [PubMed: 12656616]

(37). Qin C; Baba O; Butler WT Post-Translational Modifications of Sibling Proteins and Their Roles in Osteogenesis and Dentinogenesis. Crit. Rev. Oral Biol. Med 2004, 15 (3), 126-136. [PubMed: 15187031]

(38). Kalia J; Raines RT Hydrolytic Stability of Hydrazones and Oximes. Angew. Chem., Int. Ed 2008, 47 (39), 7523-7526. 

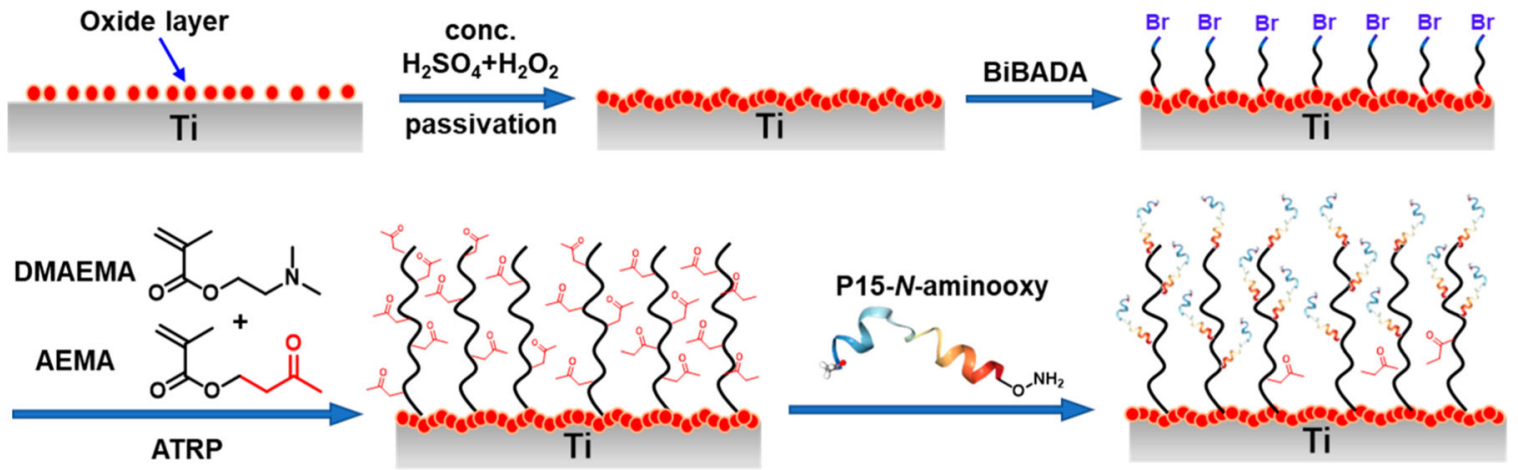

Scheme 1.

Modification of Ti Surfaces by SI-ATRP and P15 Attachment by Oxime Chemistry 
(a)

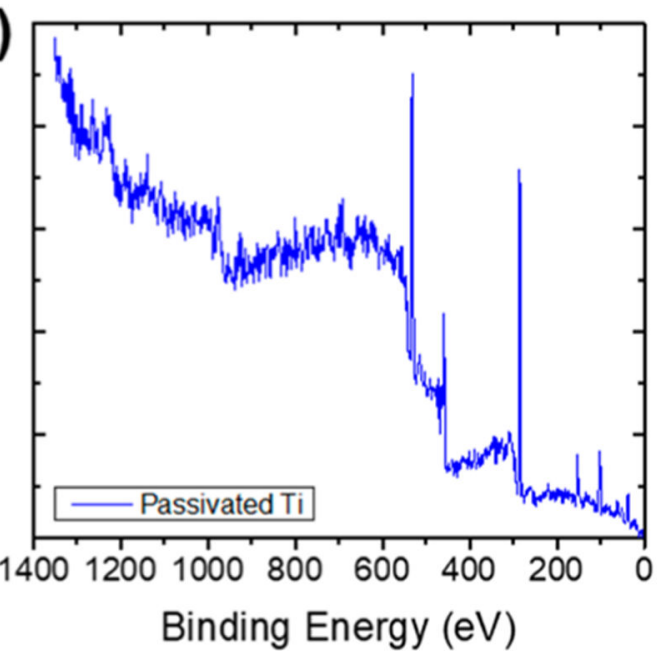

(c)

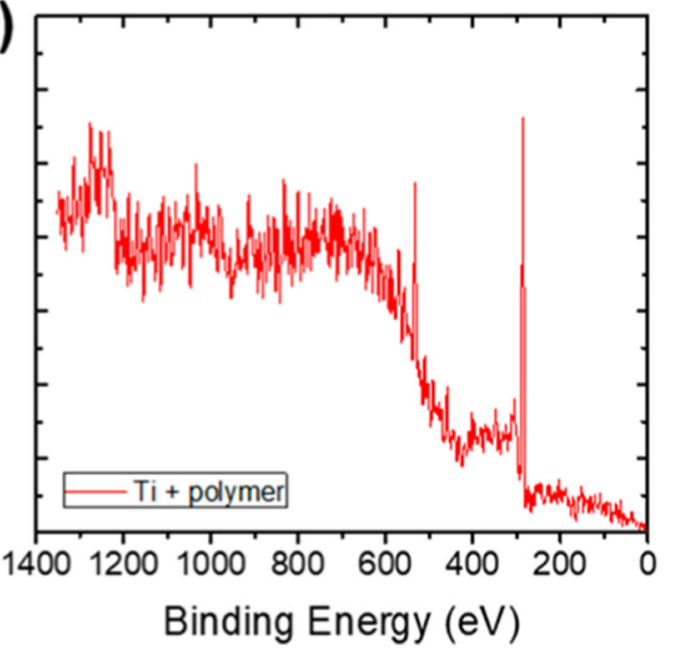

(b)

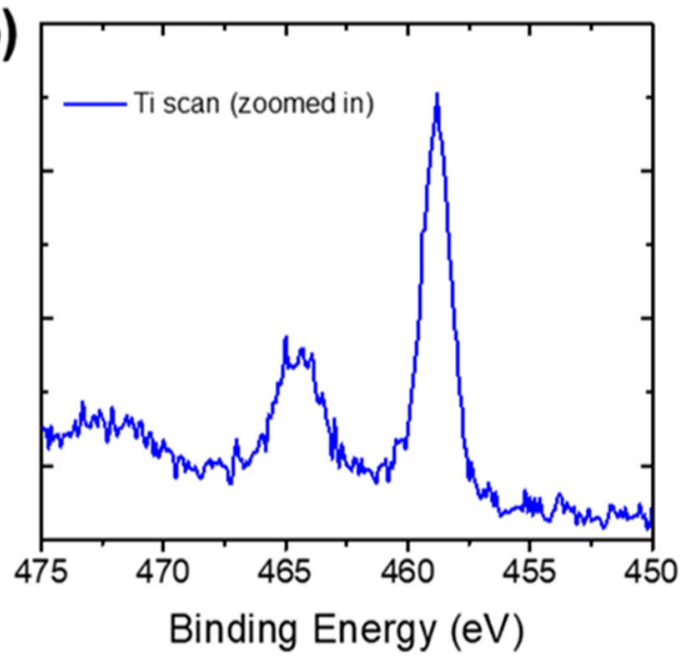

(d)

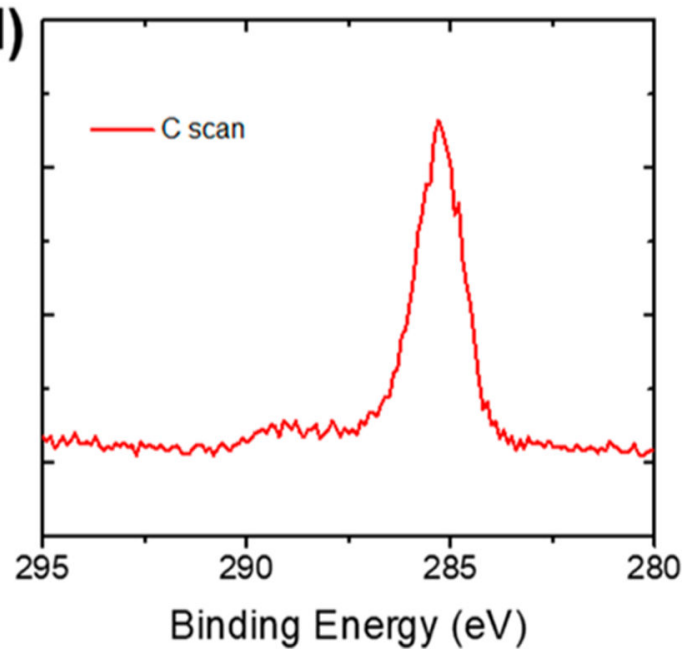

Figure 1.

XPS analysis of Ti disc surfaces with anchored BiBADA; full view (a) and Ti region zoom in (b). Ti disc surfaces with grafted polymer (pDMAEMA-co-pAEMA); full view (c) and C region zoom in (d). 

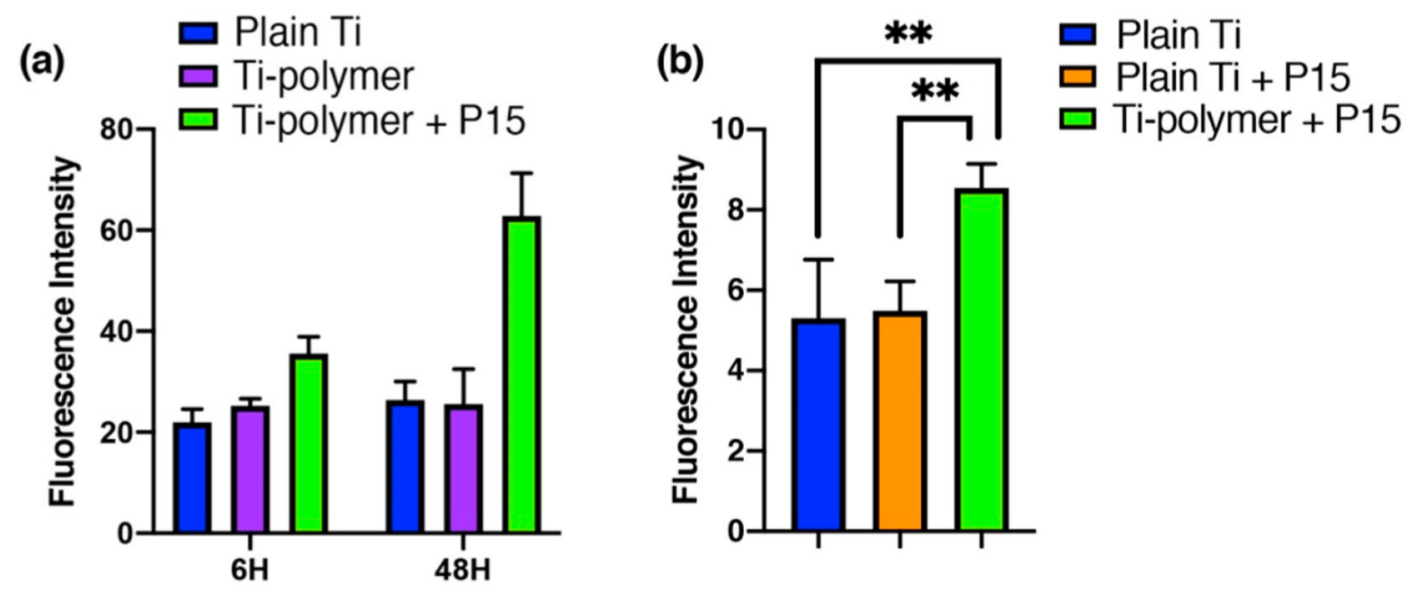

(c)

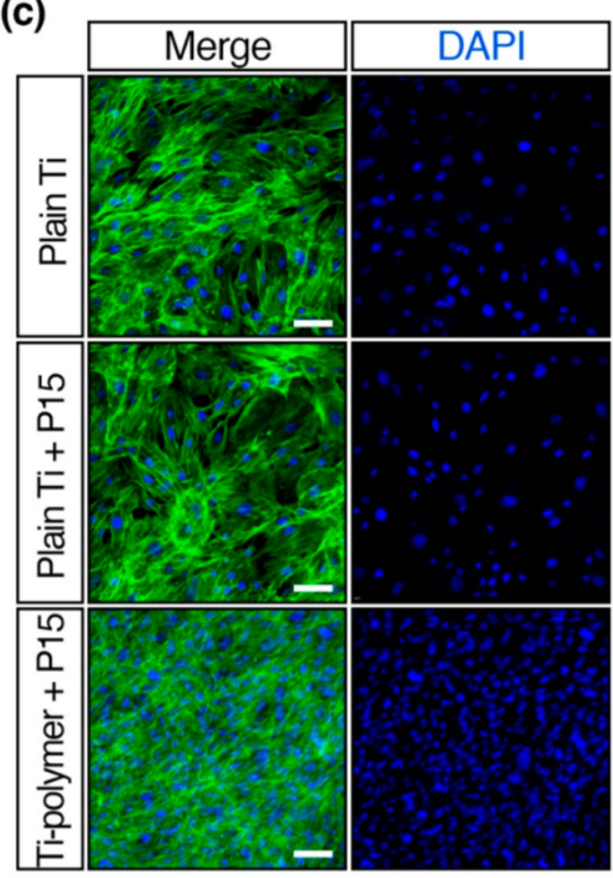

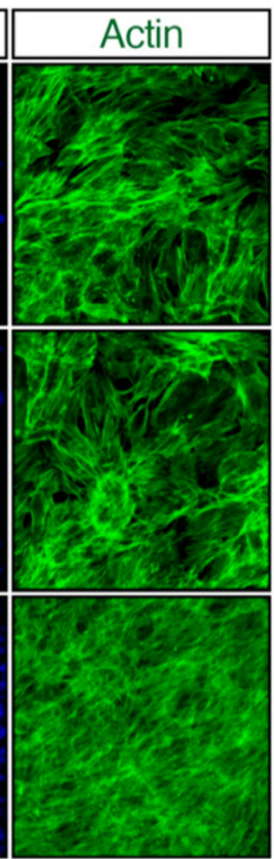

(d)

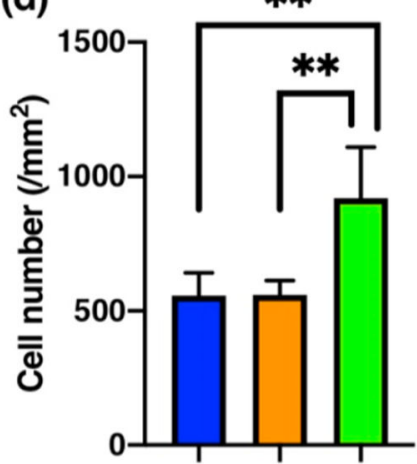

Figure 2.

Effects of the surface polymer-modified titanium surface (Ti) with P15 peptides on cell attachment. (a) The cell viability at 6 and $48 \mathrm{~h}$ were measured by alamarBlue. The polymermodified Ti surface without P15 peptides (Ti-polymer) did not promote cell viability; $n=2$. (b) The polymer-modified Ti surface with P15 peptides (Ti-polymer + P15) showed an increase in cell viability at $6 \mathrm{~h}$ compared to those of the plain Ti and the P15-adsorbed plain Ti surface (Plain Ti $+\mathrm{P} 15$ ); $n=4$. (c) Fluorescent phalloidin staining of actin at $24 \mathrm{~h}$ displayed more cells attached to the polymer-modified Ti surface with P15 peptides. Osteoblasts were stained for phalloidin (green) and nuclei were counterstained with DAPI (blue); $n=4$. (d) Quantitative analysis showed an increase in number of cells attached to the polymer-modified Ti surface with P15 peptides; $n=4$. Values represent the mean $\pm \mathrm{SD}$. **, $p<0.01$; one-way ANOVA using Tukey's test. Scale bar $=100 \mu \mathrm{m}$. 

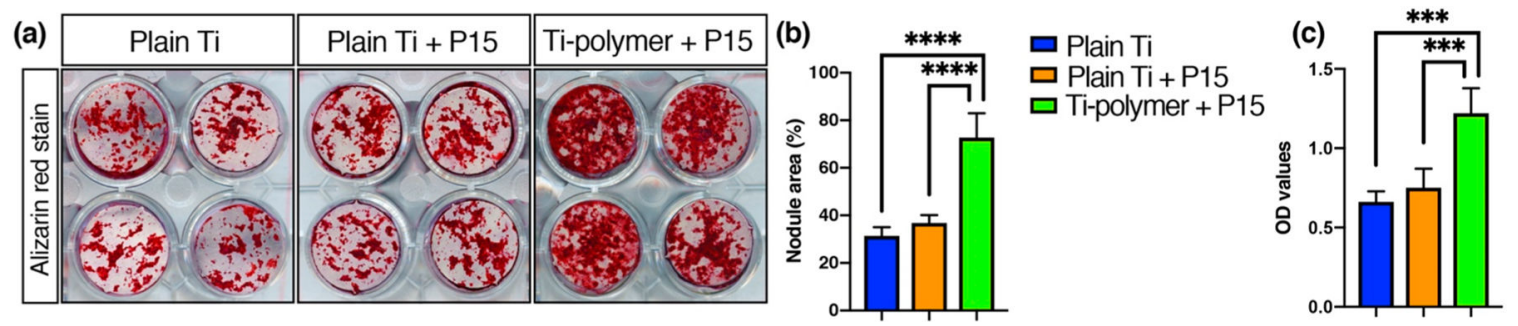

Figure 3.

Effects of surface polymer modification with P15 peptides on osteoblast mineralization. (a) Osteoblasts were incubated with osteogenic differentiation media for 21 days. Alizarin red staining was performed to visualize calcium deposition in osteoblasts. (b) The polymermodified Ti surface with P15 peptides (Ti-polymer + P15) resulted in an increase in areas of calcium nodules in osteoblasts. (c) Alizarin red was eluted and the mineral content was measured at OD570 $\mathrm{nm}$. The polymer-modified Ti surface with P15 peptide (Ti-polymer + P15) showed an increase in mineral content in culture. $n=4$. Values represent the mean \pm SD. ****, $p<0.0001 ; * * *, p<0.001$. One-way ANOVA using Tukey's test. 